\title{
Out of the trenches: An Interpretative phenomenological analysis of trainee counsellors' experiences of courage in the therapeutic domain
}

\author{
Lucy Thomas
}

\begin{abstract}
Counsellors are encouraged by the British Association for Counsellors and Psychotherapists (BACP) to periodically examine the internal values that shape the development of relationships with clients. Embedded within these values is courage - the 'capacity to act, in spite of known fears, risks and uncertainty' (BACP, 2016b) - a complex intra- and inter-personal dynamic, rarely the subject of conscious reflection. An interpretative phenomenological analysis (IPA) study using semi-structured interviews was undertaken with five counselling trainees, all attending a British educational institution and nearing the completion of their training. The research question was: What are trainee counsellors' experiences of courage in the therapeutic domain? Three themes were established as relevant to a trainee's experience of courage: courage as an expression of 'form'; courage as an ethical act; and courage expressed within systems. The review of the extant literature highlighted the multidimensional nature of courage and revealed the lack of qualitative evidence to support mainly theoretical findings. If counsellors are to consciously examine their own courage, it would seem valuable to ascertain where courage is needed and how it is experienced by fellow counsellors. The findings provide rich evidence of the embodied, holistic, and systemic nature of courage. This offers a resource for counselling trainers in the development of a courageous mindset as well as for counsellors themselves as they reflect on their ever-growing capacity for courage in their life and work.
\end{abstract}

\section{Introduction}

\section{Background}

Counsellors are encouraged by professional bodies to assess themselves in personal character development (BACP, 2016a) to enhance effective practice and ultimately foster a better society for all. Feltham (2008:25) highlights that the 'complexities of counselling' with its many variables, while negotiating the 'moral hazards in relationships and competence' (Bond, 2014:36), requires a tapestry of moral qualities undergirding ethical principles.

In a profession concerned with the alleviation of distress and suffering (BACP, 2016a), counsellors will often feel the need to call upon their own sense of moral and psychological courage. Paul Gilbert (2009:471) states 'compassionate behaviour can require us to be courageous in the face of potential shame, personal uncertainty and fear.' If courage is a prerequisite, as Freud found, describing it in a letter to a friend as 'the best thing in me' (cited in Poland, 2008:556), it would seem necessary to ascertain how counsellors currently experience their own courage; how they may better reflect on that courage to build resilience and a growing mindset to sustain them in the long haul; and additionally how they may learn from the courageous actions of others. 


\section{$\underline{\text { Research question }}$}

Using the BACP (2016b) definition of courage as a starting point for reflection, this research study asked the question: What are trainee counsellors' experiences of courage in the therapeutic domain?

\section{Literature review}

The concept of courage is universally known yet the internal psychological process is little understood (Pury and Lopez, 2010). In this review, relevant literature pertaining to courage is presented and critiqued using a chronological approach.

\section{Ancient texts to the Medieval period}

Socrates' question of Laches, 'Tell me if you can... what is courage?' (Plato and Jowett, 2012:4) has continued to stretch philosophical thinking over hundreds of decades. Aristotle, (trans. Reeve, 2014) in his writings on ethics, maintained that courage was a 'mean' between the two extremes of cowardice and rashness. The Stoical view of courage turned 'inward' with an emphasis on inner freedom and control (Soccio, 2001). The free choice of not acting was equally considered 'real' courage, and the emphasis on choice in the here and now 'moment of reflection' (Putman, 2010:15) resonates today in mindfulness practices (Williams \& Penman, 2011) and humanistic approaches (Perls, 1969, Rogers, 1967).

\section{Medieval to twentieth-century texts}

Aquinas described courage merely as a 'general' virtue (Aquinas, 1960) and included the concept of 'patience,' modifying Aristotle's work (Pury \& Lopez, 2010). While the existentialists found courage absolutely essential to the task of 'authenticity' (Kierkegaard, 1985). The latter moved to the very 'coeur' of self in advocating courage to 'be' and to 'become', overcoming the existential anxiety of 'non-being' by courageously responding to the 'thrown' experience of being in the world (Heidegger, 1927, Camus, 1942, Tillich, 1952, May, 1975). May (1975) hailed creative courage the most important of all forms of courage.

Screwtape, in C.S. Lewis' novel (1942:124), proposes 'courage is not simply one of the virtues, but the form of every virtue at the testing point', presenting an interesting angle on how courage might be experienced by counsellors and challenges the mainstream view (BACP, 2016b) that courage rests alongside other moral traits such as integrity, resilience and respect.

\section{Twenty-first-century published articles}

Faith-fuelled courage is highlighted by Medina (2008), whose seminal paper on 'everyday' courage integrates the existential, theological, and psychological literature. Five key components of 'everyday courage' are outlined: being, self-hood, choice, faith, and creativity. While the article is compelling, an existential bias is evident, and Medina highlights the lack of inter-relationship between the five components. He notes a clear need for phenomenological research and the 'lived experience of others' (Medina, 2008:295) to qualify assumptions. 
By contrast, Hannah et al.'s research into the 'courageous mindset' (2007) outlines how character differences, social forces and feedback loops can impact on courageous experience. A particular strength of this approach is in its training use in reducing counsellors' levels of fear when facing risk. However, its emphasis on positive psychology and 'positive' states largely negates the possible presence of suffering in the development of courage. Furthermore, the authors profess to the lack of empirical testing and acknowledge the 'complexities of affect, mood and neurophysiological effects on courage' (Hannah et al., 2007:134).

In 2010, editors Pury and Lopez compiled research and theoretical papers presented at the 2007 Courage Summit to form The Psychology of Courage: Modern Research on an Ancient Virtue. It was recognised that 'people need to know what, in fact, courage is in order to call on it' (Rate, 2010:63). Twelve chapters provide vital insight into this 'multidimensional' construct (Rate, 2010:51). However, the 'paucity of empirical research' (Rate, 2010:54) and large sample sizes throughout lead to 'myriad conceptualizations' of courage (Rate, 2010:62). Furthermore, small scale idiographic accounts are wholly absent.

\section{Counselling literature}

Courage is implied (if infrequently mentioned) in counselling literature and there appears to be a paucity of published articles on the subjective understanding of courage in the therapeutic realm. Hewitt's (2014:30) IPA unpublished study on courage is seemingly the only qualitative study on the topic. It highlights the cyclical nature of courage between counsellor, client and supervisor, hailing courage as the 'nexus' of therapy.

Literature that recounts the 'struggles.... self-discovery, shortcomings and disappointments' (Cozolino, 2004:205) of therapists can be useful in highlighting areas where courage is needed. For example, Mearns and Cooper's (2005) insights on working at relational depth add insight to understanding the courage of the 'here and now,' while Wosket's (1999) reflections on therapist 'failure' and the use of self are insightful for trainee counsellors. Denham-Vaughan (2010:36) explores the dialectical tension of 'will' and 'grace' in her work on the 'liminal space', which casts a fresh look at threshold moments in the 'in-between'. Her idea of 'embodied flow' (2010:40) in relationship and, along with Powlison's (2000), the learned task of stillness and patience are interesting ideas to explore in the realm of courage.

In view of the theistic worldview of the current research's sample, Benner's (1998:126) Care of Souls provides a backdrop to psycho-spiritual health, addressing freedom from 'guilt and excessive anxiety', perhaps pertinent to the present study. Benner emphasises the need for spiritual security, as do Mason and Sawyerr (2000), in pointing to secure attachment as a basis for courageous conversations.

The BACP (2016b) suggest that courage is 'the capacity to act in spite of known fears, risks and uncertainty' and, despite the BACP's reference to courage, there is a paucity of literature on the subjective understanding of courage in the counselling profession. Hewitt's (2004) IPA study stands alone as a 'lived' account of a counsellor's courage and this study will complement and add to this small body of evidence. This research question asked: How then do trainee counsellors experience courage in the therapeutic domain and what are the wider contexts influencing this phenomenon? 


\section{Methodology}

Design

In view of the moral and ethical dimensions of courage in the sphere of counselling (BACP, 2016a), it seems fitting to select a methodology that honours an individual's unique experience of the phenomenon. IPA (Smith et al., 2009) was chosen for this research. The ontological emphasis on a 'more interpretative and worldly' (Smith et al., 2009:21) critical realist position was helpful for exploring the real lived experience of counsellors as they seek to stop, step back and consciously reflect on their experience of courage in everyday situations. Being mindful of the 'third hermeneutic' (Smith et al., 2009:41) - the imagined reader - it is hoped that this research will inform future training courses as well as assist readers to reflect on the experience of courageous action in their own practice, whether in counselling or other helping contexts.

\section{Participants and ethics}

Purposive homogenous sampling (Smith et al., 2009) was used in line with the idiographic nature of the study. The sample included four females (one of whom was of non-British origin) and one male, all aged between 30 and 55 years old, and all participants shared a Christian worldview. Careful consideration was given regarding issues concerning trustworthiness, management of risk, relationships with participants and integrity of the research (Bond, 2004). Ethical approval was granted by the Waverley Abbey College Research Ethics Committee.

\section{Findings}

\section{Introduction}

Superordinate themes and related subordinate themes are presented in Table 1, followed by a brief outline of the main findings. 
Superordinate and subordinate themes

\begin{tabular}{|l|l|}
\hline Superordinate themes & Subordinate themes \\
\hline Courage as form & Use of self in sculpting the 'space' \\
& Expressed through metaphor \\
\hline Courage as an ethical Act & Expressed within tensions \\
\hline Courage within systems & Ontological to becoming \\
\hline & Specific risks \\
\hline & Attachment systems \\
\hline
\end{tabular}

Table 1: Overview of the superordinate and subordinate themes.

\section{Courage as 'form'}

Inspired by May's (1975:125) writings on courage, the word 'form' aptly describes the sense of interpersonal creativity where client and counsellor 'are struggling with their world... by constructing new forms and relationships in their world, and by achieving through proportion and perspective a world in which they can survive and live with some meaning.'

\section{Use of self in sculpting the space}

This courageous struggle for form is seen in terms of 'space'. For example, Rex' commented, 'I've felt, this is too much space for them in the sense that they almost need that shaping from me... which I find hard' and 'I've got to step out', requiring conscious choice and a sense of embodied movement. An absence of courage for Rex was experienced as a 'sense of not filling the space or not shifting to make changes', indicating the responsibility he feels to direct and shape. Steph describes movement into space: 'I can remember leaning forward slightly... and there was a push-pull going on inside $m e^{\prime}$, yet described moments of occupying space by standing ground. Alice said, 'It's a very personal thing... to really sit with that and not do anything.' Alice had 'felt cornered', yet, with the same client, described courage in the moment of commitment: 'I'm not going anywhere... I'm prepared to stay.'

\footnotetext{
1 Pseudonyms have been used.
} 
Counsellors spoke of diminishment in the presence of others and a need to change their felt 'size' to address this. Rex noted, 'I would almost say smallness... in the space of someone... he always sat on this chair that was higher up and I really got this sense of almost who am I to impose myself on him?' Rex described courage to 'step up... out' with the possibility of 'being cast down', highlighting the psychological threat to himself. Penny too describes diminishment: 'The client was everything that I felt I lacked'. Yet described an emerging moment in the use of self, saying, 'I started using my voice in a more confident natural way... the client found that very soothing... so it just emerged... so, the courage of being myself really.'. This is reminiscent of an 'Alice in Wonderland' (Carroll, 1865, Powlison, 2013) feel of constant adjustment of size until a point of mutuality in relation to the other is reached (Olthuis, 2001).

\section{Expressed through metaphor}

Metaphorical language was used by every participant to varying degrees. For Rex, a theme of war surfaced: 'It feels like... the trenches... like where you step up... out and then maybe I'm in the line of fire. It does really feel that now I can be cast down... or shot', indicating a felt sense of vulnerability and lack of resources to fight the battle. The trenches are viewed as a safe place, 'warm and friendly', a place from where he is 'driven out to do more structural stuff.' Interestingly the metaphor moves from confrontational to collaborative later in the interview, 'I will go forwards and backwards almost - times of being courageous and times of retreating. It's almost in synergy with the client, there are times when you didn't want to go there and times when you ventured forth almost... so I was with him when I was in the trenches.' It is noticeable again how Rex's subjective sense of courage is in 'venturing' alluding perhaps to the archetype of the Greek hero (Rohr, 2012).

There was a fear of sustaining injury following the action of letting oneself be 'seen'. Situations can potentially 'crush you' or be 'crippling afterwards'. Steph describes a 'wrestling between us', indicating a confrontational experience in the relationship and her courage came through in immediacy concerning the wrestle: 'the courage element for me was talking about it.' She later speaks of synergy in the metaphor of waves and reeds. "It does go in a pattern, it does go backwards and forwards... parallel, circular. I see it as a wave... like the reeds in the water going backwards and forwards.' This speaks of a fluid form, rather than fixed, of experiencing courage within the therapeutic 'dance', which will be discussed later.

Rosanna refers to a war theme in her archetypal understanding of courage. 'Soldiers in the first world war.... had to go... over the top. They knew there was a high chance they were going to be killed.' Interestingly, Rosanna diminishes her own courage in the light of greater heroes when she speaks of having a 'little bit of courage' and 'I think there is a feeling of, almost a bit of a feeling of courage there', referring to the size of her courage again in terms of form.

\section{Expressed within tensions}

Balancing tensions (such as comfort and stress) are factors common to most forms of therapy (Cozolino, 2004), and this was echoed in the participants' experiences. Rosanna senses her courage within time tensions and working within the window of tolerance (Siegel, 1999). 'A feeling of treading a tightrope... where I'm sort of watching their arousal and mood... I've only got half an hour with them left.' The tension of whether to step into another 'space' of experience (DenhamVaughan, 2010) is evident. Alice said, 'And then it kind of escalated and there was a very tentative five 
minutes when I thought, "Oh! this could go one way or the other" and "I had to make a decision. I had to be aware that it still could have gone very badly wrong.'

Rex described the feelings as being 'in no-man's land almost' with a vulnerable sense that anything could happen in that moment, and Rosanna commented on crossing into the other side of "knowing'. 'Part of you... is thinking, "Please don't tell me this! Now you've told me, I can't not know it"... so to almost have a little bit of courage to say, "I need to look at this."'

Penny highlighted the tension of controlling the session versus allowing relational flow to emerge. 'I used to write very prepared sessions and what happened in the session was very different.' Once the courage came to take off the mask, 'I start(ed) being myself and she started being herself too.'

Tensions are evident in the holistic intrapersonal multidimensional nature of courage (Rate, 2010). Steph noted, 'There was a push pull going on inside me. It wasn't fear as a gripping fear. I almost wanted to laugh at myself... this is so serious and potentially so bad... and there was tension and there was relief afterwards and that was in my body.' Alice revealed an internal 'flight' dialogue. 'This was going on in my head.. so do I tell her, "Look, I've had enough, I don't need this." On the other hand I was thinking, "There's more to this here." This is part of the therapeutic relationship... if I run away, or let her go, who am I?' It might be said that courageous intrapersonal moments are 'identity' moments.

\section{Courage as an ethical act}

Participants showed the presence of courage as part of ethical practice (Lind et al., 2010).

\section{Ethical guilt}

The presence of ethical guilt implies how much the profession drove courageous action. Courage was implied in staying with the process. Alice said, "If I run away, or if I let her go.... what kind of counsellor am I? What kind of professional am I?' Similarly, Steph commented on a lack of courage that 'feels like... it's a feeling of failure and guilt of not hitting the mark.' Rex, when asked what it is that drives him to act, said: 'It's a sense that this is the responsibility I have.'

The demands of the ethical framework (BACP, 2016) undergird action for trainee counsellors. For example, Rosanna noted, 'I needed to do it because it was ultimately in the client's best interest, not for me to put the lid on and say, "That's a bit painful."' Rex expressed it thus, 'I'll get the support beforehand so that I know what it is I should... I said should!... what is it? There's an element of "should", but actually it's deeper than that. I want to be a good counsellor... so what is it I need to be doing for that?'

\section{Ontological to becoming}

May (1975:13) states that courage is necessary in human beings to make 'being and becoming possible' and therefore 'ontological' (Tillich, 1952) - essential for every person. This is reflected in the data. For example, Penny said, 'So it just emerged... the courage of being myself really', having moved continents where she 'went through a process of metamorphosis... a process of shaping and readjusting and learning and finding a compromise.' In a similar vein, Steph said, 'Voicing what's happening for you both in the room... risking rupture, risking retreat... or getting it wrong... but I've had 
the experience that it's not failure, it is transforming, I think.' Alice stated, 'It's a process that builds for me... it's actually helped me grow into who I am.'

\section{Specific risks}

Three areas emerged requiring courage for trainees: client suicide risk, fear of rejection and facing ruptures. Rosanna on suicidal ideation: "I think there was an element of not wanting to "go there" when you see the conversation going in that direction... so to almost have a little bit of courage to say, "I need to look at this" and not back off.' Rex commented on suicidal ideation that 'there's a lot of anxiety there".

There is evidence of collusion indicating a fear of rejection as well as neglecting the 'survivor part' in clients. For example, Rosanna noted in her work with a client that 'she didn't have the ego strength to be challenged, she was too fragile, so I could make a case for how I handled it being the right way, but I was also left feeling that it was actually more about me... because she was quite fragile, she would have been offended.' Micro accounts of cognitions highlight the thought process in this regard. Penny reflected, 'That's a fear... I'm going to upset people... it is going to be bad for me, so I am very conscious about fear of making a fool of myself or shame... or feeling inadequate.'

Alice, reflecting on her cognitions when faced with ruptures, commented, 'I think I felt "Oh what have I done wrong? What's happened?"' and "Who am I? Am I good enough? Is this good enough? Do I have the tools to work with this person?"' Predominant risks in counselling have brought the micro internal processes of counsellors to the fore when searching for courage.

\section{Courage within systems}

\section{Attachment systems}

Counsellors spoke of the need of a secure base (Holmes 2001, Gerhardt, 2004, Benner, 1998) from which to venture. Rosanna commented on her anxious attachment style: 'Some people have a better foundation to be courageous in having... secure attached relationships... that still plays out in the counselling room. If I challenge people and they don't like me anymore, then I would feel devastated!' It seemed that attachment to God plays a stabilising role: 'So that's a real strength, that there's almost nothing that could happen that could take me beyond God's care.' Similarly, Rex said that a 'time of reflection, time of prayer and engaging spiritually is really important for my sense of who I am... when I don't get that space, that's when I will feel less confident.' Looking to the family and wider, Alice points to family and the environment as a basis for courageous action. She noted, 'I've got an amazing husband... and my children are really supportive. A bit of recreation, dog walking, just getting outside.'

\section{Parallel processes}

Participants brought in the parallel process of supervisor courage and counsellor courage. Rex said, 'Actually, this is the... responsibility I have... that's been developed in my training and in the supervision. My supervisor, just last week, said, "Rex, you need to be more brave." I thought "Ah, yeah I do." Alice commented on her supervisor, saying, "I've learned more from just how she is with me ... and I remember being quite shocked thinking "Whoah! Real challenge! That's really good." It gave me greater faith and trust in her experience.' 
Rosanna commented on the importance of training and research as an external 'cog', fuelling courage, saying, 'Knowledge does give me a sense, even though it feels like a painful conversation, that I know I am doing the right thing. There's being prepared, knowledgeable, being able to defend your actions... It wouldn't just be, "Well, I haven't got a clue." It would be, "Actually research indicates...".'

\section{Contexts of suffering}

Steph recognises a context of suffering has given her resources to be courageous. She noted, 'I've found that when I've had struggles in my life, I've had to face them. My broad mindset... is to face things.' Penny drew on her cultural background to frame present courageous action. 'It's already there because of my genes and my culture... I use that a lot, especially to do things that can be quite... not very... orthodox or... popular, let's say!' She recognises that a cross cultural move has changed her. 'It wasn't an easy position because it meant leaving my family, leaving my career, leaving everything... so yeah... I was very courageous at that time.'

A sense of the 'bigger picture' system motivates counsellors to act courageously. Rex reflected that, 'women down through history... [drew] courage from other people who've had to do things more difficult... There was also a sense of overwhelming joy really. "How did I do that?" Something good's going to come after the difficult time.'

\section{Summary}

The superordinate themes of creative 'form', courage as an 'ethical act', and the wider systemic influences of courage have been explored. The presence of voluntary choice, emotions, cognitive processes and behavioural responses as well as evidence of moral goals, particular character dispositions and external circumstances are echoed in the literature and will be now discussed.

\section{Discussion}

\section{Courage as 'form'}

May (1975) speaks of a passion for 'form', when counsellor and client not only seek to understand the world but are in constant engagement with each other to re-form that world. Trainees shared a holistic experience of courage in the therapeutic 'space', where a re-negotiation and re-forming of worlds was taking place.

Negotiating the 'between' of the relationship (Husserl, 1931, Buber, 1958, Clarkson, 2003) often left the participants feeling vulnerable, uncertain, and questioning their levels of involvement, control, and ability to negotiate that relationship. This was reflected in their own sense of 'size' and 'shape' as well as the push-pull feel and 'holding' of tensions. Courage emerged in changing the form of these 'in-between' dynamics balanced with caring for their own emotional wellbeing and sense of self in relationship.

Mearns and Cooper (2005:160) highlight the importance of the dyadic relationship where 'both people contribute and both are shaped by the influence of the other.' Being able to sit with dissonance, and the 'variable process' (2005:161) as well as increasingly being able to reflect on 'under-involvement' or 'over-involvement' are assumed to be part of a trainee counsellor's learning and not something of which to be afraid. 
Spence and Smythe (2007, cited in Lindh et al. 2010:563) describe courage 'in relation to creating opportunities in a space between chance and security.' Denham-Vaughan (2010:35) in her writings on the 'liminal space' speaks of reflecting on one's response to these opportunities: 'whether we shrink, fall back, go boldly forward, leap ahead, wobble.' These varied experiences were shared by most participants, where forward movement inferred courage and 'shrinking' or staying in a 'retreated' position was deemed as an absence of courage, even shameful.

The pervading presence of threat and tentativeness expressed through metaphor as well as pervasive self-questioning and fight/flight experiences in the moment might indicate a limited skill set in managing transitional courageous moments. Denham-Vaughan's (2010:41) twelve elements point to a useful framework in negotiating the 'space' of the dyadic relationship, where perhaps a softer 'willingness to risk stepping out into the new and assessing the impact of this step upon ourselves and our situation' might replace the heightened anxiety evidenced in the data, possibly arising from a harsher, 'fixed', self-critical thinking pattern.

It was notable how few participants commented on the courage to be 'still' (Powlison, 2000), allow a moment to 'emerge' (May, 1975) and 'catch the wave' (Denham-Vaughan, 2010:43) as it arrived.

The findings resonate more closely with the work of Olthuis (2001:151) who describes 'a wild space' that can be 'unchartered, unpredictable and risky.' Olthuis speaks in terms of zigzagging movements 'however oblique a route we must take to spiral to port' (2001:161). The process of 'with-ing' (Olthuis, 2001, 2006) echoes what most trainees experience in the data - a tug-of-war attack or collusion, keeping distant from the client, 'retrenching instead of releasing' (Olthuis, 2001:162) - leading to a gradual mutuality and flow in relationship, which was reflected by Steph in the metaphor of the reeds and the wave and an emerging collaborative relationship.

Cozolino (2004) highlights, along with other therapists (Mearns and Cooper, 2005, Kearns, 2007, Wosket, 1999), the need to embrace mistakes, 'failure' and ruptures. Within the interviews, the participants expressed some all-or-nothing, 'right-or-wrong' thinking patterns with an over-riding sense of responsibility for the session. Denham-Vaughan (2010:40) sheds lights on this complex intrapersonal process experienced by most trainee counsellors. 'We are constantly making numerous value-based judgements concerning what to pay attention to, what to raise awareness of, which aspects of this data to convey to the other and when to pass along the information.' If trainee counsellors were to practise self-compassion in this area, realising the complexity and time it takes to reflect upon and learn this 'dance', I wonder if there would be less fear and anxiety present in a session? Courage in this sense would be in 'inhabiting the multitudinous thresholds offered in every moment' (Denham-Vaughan, 2010), whether that be a forwards motion, a backwards motion, or a sense of resting in that moment.

\section{Courage as an ethical act}

Pury, Lopez and Key-Roberts (2010:229) describe moral courage as 'standing up for what is right in the face of disapproval. It is associated with risk to one's image and can include rejection... Individuals with moral courage make choices that benefit the common good rather than their own interests.' The study revealed participants' desires to fulfil certain ethical and training requirements (BACP, 2016a) highlighted by the presence of ethical 'guilt' (Lindh et al., 2010). It also highlighted inner vulnerabilities and fears leading to people pleasing and collusion. Thorup et al. 
(2012) call for a need to 'dare to accept the possibility of rejection' and the courage to confront oneself, 'being confident of (one's) completeness as a human being' (2012:433).

Cozolino (2004:207) states that 'personal failure is an essential part of development... failure in relationships provides opportunity to repair what has been ruptured.' Wosket (1999), Clarkson (2003) and Mearns \& Cooper (2005) write extensively on failure, espousing that failure brings us in touch with our humanity and that paradoxically our most courageous moments may be in sharing, admitting, and reflecting on 'failures' (evidenced solely by Steph, who recounts courage in 'immediacy' moments). Clarkson (2003:142) goes further in suggesting it is necessary to fail clients, which in turn builds up resilience and a strong core self.

It might be suggested that trainee counsellors could reduce the amount of fear and the subsequent requirement for 'courageous' action if they were able to accept and hold their own weaknesses (Cozolino, 2004); embrace the need for courage in welcoming 'failure' and release themselves from over-responsibility for outcomes knowing that the client is the main predictor of 'success' (Cooper, 2008). Medina's (2008:291) idea of the courage to 'achieve less' and allowing the space to be filled with 'stuckness' may be releasing for trainees who feel an overwhelming sense of responsibility.

The study deepened the researcher's understanding of trainee counsellors' positive voluntary intentions, reminiscent of Gruber's (2011) work on cognitive, voluntary 'intention' in courage. These cognitive micro processes were evidenced in the data. However, it became clear that trainee counsellors would tend to 'sacrifice' themselves, thus calling into question the ethical principle of self-respect (BACP, 2016b) and that both beneficence and self-respect need to be balanced for ethical practice.

Trainee counsellors experienced courage as a self-actualizing process, which resonated with the existentialist literature (Tillich, 1952, May, 1975). Medina (2008) draws on existentialist writers to develop his concept of 'everyday courage' where the 'battlefield' is seen in everyday life, an impression echoed in the research data with the war metaphor. There was a shared experience of courage in the continual embodied experience of decision making, emotional regulation and in the struggle to maintain a sense of identity, knowing that in simply being involved in the world of the client we 'are also constantly in danger of losing our sense of self in the relational dimension... without an everyday courageous dedication to plot our own course' (Medina, 2008:287). The data showed abundant evidence of the process of becoming more 'themselves' through the conscious choices made and the opportunity to reflect on courageous practice. Cozolino (2004:207) concurs that in the process of helping others, we are 'simultaneously discovering ourselves.'

\section{Courage within systems}

Tim Bond (2014:39) in writing on his work with HIV AIDS clients was mindful of his need for 'the moral courage of others' to negotiate this new territory in counselling. Likewise, the data shows that trainee counsellors are inspired by courageous 'others', whether that be church, family, professional circles or archetypal figures or their own felt sense of being part of a bigger spiritual narrative.

Hannah et al.'s (2007) courageous mindset approach affirms how social forces interact with personal values to moderate courageous behaviour in the presence of fear. It is proposed that a 
person's core value and belief system 'exerts significant psychological pressure' (Hannah et al., 2007:133) to be congruent in the face of fear and that universal values promote courageous behaviour (Peterson and Seligman, 2004, cited in Hannah et al., 2007). Trainee counsellors' spiritual belief systems, cultural and archetypal systems were evident in the data in driving courageous action.

Trainee counsellors described how secure attachments, whether physical or spiritual, enhanced courageous practice, resonating with systemic counselling literature (Mason and Sawyyer, 2002) and Benner's (1998) work on developing psycho-spiritual maturity. These counsellors 'are therefore, content to be with the other... who will be with them in the midst of whatever they face, thereby mediating the grace of God who is also with them' (Benner, 1998: 211). The data revealed counsellors' doubts over issues of identity, their struggle at times to feel 'centred', yet their frequent return to 'secure bases' (Holmes, 2001).

Suffering as a context for growth in virtues is a well-known theme in spiritual contexts and trainee counsellors who hold a Christian worldview predominantly connect pain and struggle with growing courage as evidenced in the data. Thompson (2006, cited in Woodard, 2010:116) speaks of the 'wisdom of submitting to suffering and making use of it' in the pursuit of authentic living.

Olthuis (2001:199) reflects on therapists of faith and their ability to 'suffer-with', 'Knowing that we need not dispel the darkness ourselves because the darkness has been dispelled... we can gather up our courage and cry with those who cry and groan with those who groan - because there is hope.' Keller (2015:285) casts an interesting light on courage in a spiritual context, suggesting that in 'feeling the fear' (Jeffers, 2007) and having an 'I can do it' attitude is not purely self-confidence. It is when we have an over-riding sense that 'this is more important than me' (i.e.,love for God) that we can know 'true courage'. Surely a combination of internal strength as well as a connection with an overarching 'telos' narrative is a potent combination for courageous action.

Several participants highlighted the importance of a parallel process between supervisor, counsellor and client, as well as the restorative function of supervision in counsellors being encouraged to re-enter sessions with a strengthened core self. This evidence gives strength to Hewitt's (2014) thesis on therapeutic courage in parallel and cyclical relationships.

Lester et al. (2010) advocate not only being influenced by relationships but to actively seek out training in courage. They state, 'perhaps one of the greatest hurdles to developing courage in a protégé is his or her understanding of where and how one is expected to show courage in a given profession' (2010:198). The data in this research showed that trainee counsellors rarely considered and reflected upon courageous action and were unsure as to what might be considered courageous or not. Aristotle's (trans. Reeve, 2014) view that courage is the mean between two extremes points to the need to 'practise the mean until it becomes a more or less natural tendency' (Putman, 2010:11).

Training systems (alluded to by the participants) echo Thorup et al.'s (2012:433) statement that 'certainty and knowledge enhance... courage and improve... confidence' when making decisions, while recognising that paradoxically it is only the 'courageous who dare not to know anything for sure' (Spence and Smythe, 2007 cited in Thorup et al., 2012:433). 


\section{$\underline{\text { Limitations }}$}

The limitations mainly concern the sample and scope of the study. Of five participants, only one was male and a more balanced sample in term of gender would have been preferable. In terms of diversity, four were white English and one originated from the southern hemisphere, providing interesting insights in terms of metaphor and cultural influence, yet diluting the sample's homogeneity.

Of note is the researcher's relationship with the participants. Three out of five were fellow students on the same course, the remaining two from different courses at the institution. An empathic relationship was quickly established with those known to the researcher, producing honest, authentic accounts quickly. However, it was an intentional act to maintain a researcher's stance, bracketing possible biases and ideas about what the interview might produce (Smith et al., 2009).

It is recognised that this is a small-scale study, which, due to wordcount restrictions, was unable to address the wider circular and parallel processes in detail. As stated in the literature review, however, a small idiographic study such as this may serve the wider body of literature well in detailing the lived experience of counsellors sharing a Christian worldview.

The findings point to further areas of interest for research such as: the experience of courage within a specific counselling context; the experience of courage in 'mature' counsellors; the relationship between attachment, spirituality and courage; a further exploration of courage at threshold moments and in the 'liminal space' following training in this area; and an exploration of the inclusion of 'the courageous mind' as an integrative aspect of a therapeutic approach.

\section{Conclusion}

The subjective experience of courage, seen through the lens of trainee counsellors, has shown how an individual's experience, context, character traits and personal dispositions play a part in their own courageous understanding. Courage was experienced as a holistic creative act, changing form and shape throughout the dialogic process and at crucial threshold moments. Furthermore, courage was inextricably linked to systems in the individual's life and driven by ethical expectations.

The opportunity to reflect on courage (a subject previously unconsidered) was experienced as transformational by all participants, building a sense of confidence in their own courage and in the acknowledgement that in acting courageously, participants were becoming more and more authentically 'themselves'. The 'personal moral quality' of courage has been 'consciously examined' (BACP, 2016b) by five trainee counsellors, and a new curiosity and enquiry into the subjective nature of this courage has been stirred. In the words of Rate (2010:64) may this exploration into the nature and meaning of courage be 'simply the beginning of another'. 
Out of the Trenches: An interpretative phenomenological analysis of trainee counsellors' experiences of courage in the therapeutic domain.

\section{Reference list}

Aquinas, T. (1960) St Thomas Aquinas: Philosophical Texts (T. Gilby, trans.). New York: Galaxy Books.

Aristotle (2014) Nichomachean Ethics (trans. Reeve). Accessed through:

https://www.google.co.uk/books/edition/_/Rq3xAgAAQBAJ?hl=en\&gbpv=1\&pg=PP1\&dq=nicomac hean+ethics [Accessed: 22/11/2021]

Ashley, O. (2013) A Theological and Practical Evaluation of CWR's Waverley Christian Counselling Model. Farnham: CWR.

BACP (2016a) Ethical Framework for the Counselling Professions. Therapy Today. 27(6) pp. 16-21.

BACP (2016b) Ethical Framework for the Counselling Professions. Lutterworth: BACP. Accessed through:

http://www.bacp.co.uk/events/learning_programmes/ethical_framework/documents/ethicalfram ework_mono.pdf [Accessed: October 2016]

Benner, D. (1998) The Care of Souls. Grand Rapids: Baker Publishing Group.

Bond, T. (2004) Ethical Guidelines for Researching Counselling and Psychotherapy. Rugby: BACP.

Bond, T. (2014) The Quest for Moral Purpose. Therapy Today. 25(2) pp. 36-39.

Braun, V. and Clark, V. (2006) Using Thematic Analysis in Psychology. Qualitative Research in Psychology. 3 pp. 77-101.

Buber, M. (1923/1958) I and Thou (Trans. R.G. Smith). New York: Scribner.

Camus, A. (1942) Le Myth de Sisyphe. Editions Gallimard: folio essays.

Carroll, L. (1865) Alice in Wonderland. New York: HarperCollins.

Clarkson, P. (2003) The Therapeutic Relationship ( $2^{\text {nd }}$ ed.). London: Whurr.

Cooper, M. (2008) Essential Research Findings in Counselling and Psychotherapy. London: SAGE.

Cooper, M. and Dryden, W. (2016) The Handbook of Pluralistic Counselling and Psychotherapy. London: SAGE.

Cozolino, L.J. (2004) The Making of a Therapist. New York: Norton.

Denham-Vaughan, S. (2010) The liminal space and twelve action practices for gracious living. British Gestalt Journal. 19(2) pp. 34-45.

Feltham, C. (2008) Therapy is not a Science. Therapy Today. 19 (7) p. 25.

Finlay, L. (2002) Negotiating the Swamp: the opportunity and challenge of reflexivity in research practice. Qualitative Research. 2 pp. 209-230. 
Finlay, L. (2008). A dance between the reduction and reflexivity: Explicating the "phenomenological psychological attitude". Journal of Phenomenological Psychology. 39 pp. 1-32.

Finlay L. \& C. Ballinger (2006) Glossary. In: Finlay L, Ballinger C (eds) Qualitative Research for Allied Health Professionals: Challenging Choices. Whurr Publishers, Chichester.

Freud, S. (1994) Letter from Sigmund Freud to Sandor Firenczi, October 17, 1910. In E. Brabant, E. Faldezer and Gampieri-Deutsch, P. (eds.) The Correspondence of Sigmund Freud and Sandor Firenzi (1908-1914) (Trans. P. Hoffer). Cambridge: Belknap Press.

Gerhardt, S. (2004) Why Love Matters. Hove: Brunner-Routledge.

Gilbert, P. (2009) The Compassionate Mind. London: Constable.

Gruber, C. (2011) The Psychology of Courage. Modern Research on an Ancient Virtue. Integrative Psychological and Behavioural Science. 45 pp. 272-279.

Hannah, S.T., Sweeney, P.J., \& Lester, P.B. (2007) Towards a courageous mindset: The subjective act and experience of courage. The Journal of Positive Psychology. 2(2) pp. 129-135.

Hannah, S.T., Sweeney, P.J., \& Lester, P.B. (2010) The Courageous Mind-Set: A Dynamic Personality System Approach to Courage. In Pury, C.L.S. and Lopez, S.J. (eds.). The Psychology of Courage: Modern Research on an Ancient Virtue. Washington DC: American Psychological Association. pp. 125-149.

Heidegger, M. (1927/62) Being and Time. Oxford: Blackwell.

Hewitt, S.E. (2014) The unfolding heart: What is the nature of courage in the therapeutic domain from the dual perspective of counsellors' personal therapy and their clinical practice? A qualitative study evaluated by Interpretative phenomenological analysis. University of Chester. Available at: https://chesterrep.openrepository.com/cdr/handle/10034/326264 [Accessed October 2016]

Holmes, J. (2001) The Search for the Secure Base. Hove: Routledge.

Husserl, E. (1931) Ideas: General Introduction to Phenomenology. Macmillan, New York.

Jeffers, S. (1987) Feel the Fear and Do it Anyway. Pensacola: Ballinger Publishing.

Kearns, A. (2007) The Mirror Crack'd: when good enough therapy goes wrong and other cautionary tales for humanistic practitioners. London: Karnac.

Keller, T. (2015) My Rock. My Refuge. London: Hodder and Stoughton.

Kierkegaard, S. (1985) Fear and Trembling (Trans. A. Hannay). Harmondsworth: Penguin Books.

Lester, P.B., Vogelgesang, G.R., Hannah, S.T., and Kimmey Jr., T. (2010) Developing Courage in Followers: Theoretical and Applied Perspectives. In Pury, C.L.S. and Lopez, S.J. (eds.) The Psychology of Courage: Modern Research on an Ancient Virtue. Washington DC: American Psychological Association. pp. 187-209. 
Lewis, C.S. (1942) The Screwtape Letters. London: HarperCollins.

Lindh, I., da Silva, A.B., Berg, A., \& Severinsson, E. (2010) Courage and Nursing Practice: A Theoretical Analysis. Nursing Ethics. 17(5) pp. 551-565.

Lopez, S.J., Rasmusesen, H.N., Skorupski, W.P., Koetting, K., Petersen, S.E., and Yang, Y. (2010) Folk Conceptualizations of Courage. In C.L.S. Pury, and S.J. Lopez, (eds.) The Psychology of Courage: Modern Research on an Ancient Virtue. Washington DC: American Psychological Association. pp. 2347.

Mason, B. and Sawyerr, A. (eds.) (2002) Exploring the Unsaid: Creativity, Risks and Dilemmas in Working Cross Culturally. London: Karnac.

May, R. (1975) The Courage to Create. London: Norton.

Mearns, D., \& Cooper, M. (2005) Working at Relational Depth. London: Sage.

Medina, M. (2008) Everyday Courage. Living Courageously Without Being a Hero. Existential Analysis, 19(2) pp. 280-298.

Olthuis, J. (2001) The Beautiful Risk. Grand Rapids: Zondervan.

Olthuis, J. (2006) With-ing: A Psychotherapy of Love. Journal of Psychology and Theology. 34(2) pp. 66-77.

Perls, F.S. (1969) Gestalt Therapy Verbatim. Moab: Real People Press.

Peterson, C. \& M. Seligman (2004) Character Strengths and Virtues. New York: Oxford University Press.

Plato \& Jowett, B. (2012) Laches. A public domain book. [Kindle Edition]. Accessed from: www.amazon.co.uk [Accessed 12/2016]

Poland, W.S. (2008) "The Best Thing in Me": The Analyst's Courage in Clinical Practice. Psychodynamic Psychology. 25(3) pp.556-559.

Powlison, D. (2000) "Peace, be still" - Learning Psalm 131 by Heart. Journal of Biblical Counselling. 18(3).

Powlison, D. (2013) “Peace, be still” - Learning Psalm 131 by Heart. In Essentials: Three classic articles from the Journal of Biblical Counselling. Leyland: CCEF. pp.14-26.

Pury, C.L.S., and Lopez, S.J. (eds.) (2010) The Psychology of Courage: Modern Research on an Ancient Virtue. Washington DC: American Psychological Association.

Pury, C.L.S., Lopez, S.J. \& Key-Roberts, M. (2010). The Future of Courage Research. In C.L.S. Pury and S.J. Lopez (eds.) The Psychology of Courage: Modern Research on an Ancient Virtue. Washington DC: American Psychological Association. pp. 229-237.

Putman, D. (2004) Psychological Courage. Lanham: University Press of America. 
Putman, D. (2010) Philosophical Roots of the Concept of Courage. In C.L.S. Pury, and S.J. Lopez, (eds.) The Psychology of Courage: Modern Research on an Ancient Virtue. Washington DC: American Psychological Association. pp. 9-23.

Rachman, S.J. (2010) Courage. A Psychological Perspective. In C.L.S Pury,. and S.J. Lopez, (eds.) The Psychology of Courage: Modern Research on an Ancient Virtue. Washington DC: American Psychological Association. pp. 91-109.

Rate, C.R. (2010) Defining the Features of Courage: A Search for Meaning. In C.L.S. Pury, and S.J. Lopez, (eds.) The Psychology of Courage: Modern Research on an Ancient Virtue. Washington DC: American Psychological Association. pp. 47-67.

Rogers, C. R. (1967) On Becoming a Person: A Therapist's View of Therapy. London: Constable and Co. Rohr, R. (2012) Falling Upward. London: SPCK.

Smith, J., Flowers, P. and Larkin, M. (2009) Interpretative phenomenological analysis: theory, method and research. London: Sage.

Soccio, D. (2001) Archetypes of Wisdom (4th ed.). Belmont: Wadesworth.

Spence, D. and Smythe, L. (2007) Courage as Integral to Advanced Nursing Practice. Nursing Praxis. 23(2) pp. 43-55.

Thompson, M.G. (2006) Vicissitudes of authenticity in the psychoanalytic situation. Contemporary Psychoanalysis. 42 pp. 139-176.

Thompson, F.C. (ed.) The Bible, New International Version. London: Hodder \& Stoughton.

Tillich, P. (1952) The Courage to Be. Yale University Press. Accessed through:

https://www.google.co.uk/books/edition/The Courage to Be/WEz3kAHzMrEC?q=the+Courage+to + Be+Tillich\&gbpv $=1 \# f=$ false [Accessed: $22 / 11 / 2021]$

Thorup, C.B., Rundqvist, E., Roberts, C. and Delmar, C. (2012) Care as a Matter of Courage: vulnerability, suffering and ethical formation in nursing care. Scandanavian Journal of Caring Sciences. 26 pp.427-435.

Williams, M. and Penman, D. (2011) Mindfulness: a practical guide to finding peace in a frantic world. London: Hachette Digital.

Woodard, C.R. (2010) Understanding the Role of Courage in Social Life. In C.L.S. Pury, and S. J. Lopez, (eds.) The Psychology of Courage: Modern Research on an Ancient Virtue. Washington DC: American Psychological Association. pp. 109-125.

Worline, M.C., Wrzesniewski, A. \& Rafaeili, A. (2002) Courage and Work: Breaking routines to improve performance. In Lord, R., Klimoski, R. \& R. Kanfer (eds.) Emotions at work. San Francisco: Jossey-Bass. 
Worline, M.C. (2010) Understanding the Role of Courage in Social Life. In C.L.S. Pury, and S. J. Lopez, (eds.) The Psychology of Courage: Modern Research on an Ancient Virtue. Washington DC: American Psychological Association. pp.209-227.

Wosket, V. (1999) The Therapeutic Use of Self. Hove: Routledge.

\section{About the author}

Lucy Thomas MA, BSc (Hons), MBACP (Accred), MACC

Having gained her MA qualification from Waverley Abbey College / Roehampton University in Integrative Counselling in 2017, Lucy has been working in private practice with young people, adults and couples. Over the past year, she has also been working as an Employee Assistance Advisor with Optima Health. She particularly enjoys working with local charities in Reading, providing counselling support to frontline staff as they serve the town.

Over the last ten years, Lucy has served as a deacon for marriage strengthening and marriage preparation at her local Church and is passionate about welcome, inclusion, hospitality and creating spaces where people feel seen and heard.

Contact: Lucy Thomas Counselling: www.readingcounselling.co.uk

\section{Copyright}

Copyright 2021 Lucy Thomas 